\title{
Factors Influencing Customers' Purchase aße Intention towards Local Clothing Brands in Bangladesh
}

\author{
Mouri Mehtaj \\ Lecturer, School of Business and Economics, United International University, Dhanmondi-1209, Dhaka, BANGLADESH \\ *E-mail for correspondence: mourimehtaj@ymail.com \\ Received: May 13, 2017; \\ Accepted: July 22, 2017; \\ Published: Sep 23, 2017 \\ Source of Support: Nil \\ No Conflict of Interest: Declared

\begin{abstract}
This study is an attempt to determine the factors influencing customers to purchase local clothing brands. Data was collected through self-administered questionnaire. Total 350 respondents from specific geographical areas (Dhaka, Chittagong and Sylhet) have been selected to conduct the study. Cross tabulation was used for the analysis of collected data under the support of IBM SPSS 16 . The study addressed some important features regarding choice of clothes. The findings indicate that quality is the first priority among all the factors for preferring local brands. Promotional activities have more influence on male customers instead of female customers. Other factors like variation, reasonable price and scope for change are less important factors for the adult buyers.
\end{abstract}

Keywords: Influence, purchase, brands, quality, scope for change

\section{INTRODUCTION}

Purchase intension is one of the crucial elements to consider and evaluate the product by any consumer. It basically refers to the affection of people that makes them buying the specific product and service in the future (Business Dictionary, 2010.) The motive behind such interest is the belief of people that the product can give satisfaction to them. Once a customer is satisfied by evaluating any product, he or she will be habituated with it gradually. Purchase intention may classify as one of the mechanisms of how a particular intention turned into purchase a particular product (Fitzsimons and Morwitz, 1996). This mechanism depends on variables such as customers' purchase deliberation and expectation towards the product (Laroche and Zhou, 1996).

Brand is the method to differentiate a product from competing products for the purpose of satisfying the similar need (Biplob, S. B., 1998). These differences may be intangible, emotional, symbolic, tangible or rational. There is a close relation between positive brand image and purchase intension of consumers. To increase the value of the brand in customer's mind, one has to ensure brand loyalty. Thus, customers can keep faith on the brand over a long period of time.

Clothing is completely a human nature that started at primary stage of civilization. Anthropologists believe that animal skins and vegetation were used as a cover to protect from cold, sun and rain. Another hypothesis is that factors such as magic, decorative, cult or prestige are the purposes of covering the human body. Now, the purpose of clothing is quite different than the beginning stage of human life. It is found to be practical and realistic to wear clothes as a symbol of civilization.

This is the era of Globalization which is a dominant component for emerging the fashion industry all over the world. Globalization is gradually reducing the homogeneity of consumer behaviours within different areas (Cleveland and Laroche, 2007). Moreover, fashion events and fashion advertisements on media have great impact on young consumers living in different countries. Recently, many internationally recognized brands are trying to bring down intercultural differences in clothes. Calvin Klein, Hugo Boss, H \& M, Zara, Ralph Lauren Corporation, Armani are some of the popular global brands target the customers all over the world.

Bangladesh, a South Asian country, has readymade garments (RMG) sector which is the biggest foreign currency earner. By creating about 4.2 million employment, this industry exported the products with the value over $\$ 24.49$ billion which is consisted $76 \%$ of our total export earnings in 2015 (www.garmentsmerchandising.com). Consultancy firm Mckinsey and Company said that Bangladesh could 
double its garment exports in the next 10 years. Undoubtedly, it is a positive news that our garments are not only fulfilling the local and global needs, but also enhancing the national economy.

Bangladeshi people are generally traditional to choose their dresses. Men usually prefer shirt, t-shirt, punjabi, lungi, trousers whereas women prefer sharee and salwar kamij. Recently, our fashion industry has been greatly changed due to the globalization process. People are getting attracted to the western style. In the early 1990's the demand for readymade wears was not very significant. Bangladeshi people preferred to purchase clothes and get their outfits tailored. From onward 2000's, customers switched to readymade cloth gradually because of the changing social and economic status as well as the life styles. The concept "Branding" came to light in the apperal market of Bangladesh both for male and female consumers. Currently, a wide range of local apperal brands are present in the market such as Aarong, Cat's Eye, Anjans, Yellow, Westecs, Kay Kraft, Bibiana, Artisti, Ecstacy, ShadaKalo, Richman, Deshal, OG, Plus Point, Nair and many more. Customers of different ages and income levels are having these brands because of quality, reasonable price, and scope for change, variation or attractive promotional activities.

\section{REVIEW OF LITERATURE}

Purchase intention turns into implication when customers are most likely attempting to buy products or services (Dodds, Monroe and Garewal, 1991). For businesspersons, purchase intention means "forecasted consumer behaviour" which is interdependent on purchase desire of the customers (Rizwan et al., 2013). The consumers have positive attitudes towards international branded products (Kinra, 2006). Successful brand can satisfy the consumers of that particular brand (Hsieh, Pan and Setiono, 2004). It can also differentiate the brands from the competitors and increase the possibility for customers to buy the products of that particular brand again (Hsieh, Pan and Setiono, 2004).

A study headed "Brand Preferences of Men's wear" by Lalitha et al., (2008) pointed on preferring the brand regarding shirts as well as trousers of specific consumers living in "Two Cities of Hydrabad and Secunderabad". The purposes of this study were to find the reason of preferring branded dress instead of unbranded one, to realize the effect of advertisement for branded dress and to understand the reasons influencing customers to select branded trousers or shirts. It is figured that employment status, educational qualifications, age bracket, convenience of markets and tvc are motivators for purchasing the branded clothing by the respondents. The study revealed $94 \%$ respondents are highly informed and purchased branded clothes. Customers of 20-50 years have a tendency to spend on the branded wears. Moreover, 54\% customers prefer purchasing branded dresses because of status symbol and quality.

Narag (2006) supervised a study based on Luckhnow city. It is entitled "A Study on Branded Men's wear." The purpose of this research was to know the buying behaviour of customers regarding branded men's wear. The study showed that promotional activities can influence significantly on purchase decision of buyers. This research figured that most of the buyers visit the showrooms of branded dresses with the intention of shopping. Moreover, Pathak and Tripath (2009) conducted a study entitled "Consumer Shopping Behaviour among Modern Retail Formats: A Study of Delhi and NCR." It pointed on consumer shopping habit in India among the "Modern Retail Formats". The study expressed that young consumers get fascinated to the branded clothing because of trust and comfort.

There is a strong link between consumer purchase motive and product knowledge (Kempf and Smith, 1998). Informed and knowledgeable consumers are capable of assessing branded products more accurately. They have more favourable attitude toward branded items. Low price; on the other hand, is a very significant causal issue that affects demand for copied goods (Dodge et al. 1996; Miller, 1999; Prendergast et al. 2002; Harvey and Walls, 2003). Customers are interested to purchase contemporary products but not all of them can effort them. Those who can't acquire innovative brands, the best priced real brands give a chance to low priced counterfeits to complete their brands (Prendergast et al. 2002). Cost factor is always given importance by price concern buyers. (Haque et al. 2009; Gino, 2010).

Consumers' past behavior can offer effective predictions of purchase intentions (Bentlar and Speckart, 1979). Having better past experience makes the customer more loyal and furthermore serves as a brand equity in future (DelgadoBallester, 2005). Moreover, income level of consumers, price, fitting are significant motivators and celebrity endorsement, status, durability are insignificant motivators to buy clothes in India (Rajput, 2012). On the other hand, readymade garments are mostly acquired during discount period (Mittal and Aggarwal, 2012; Pandian et al, 2012; Kanthi and Kumar, 2013). Also, need for uniqueness and self-concept influence clothing interest of customers (Vikkraman and Sumathi, 2012). Availability, better fitting, varities and latest design are responsible for young segment to use branded dress (Sawant, 2012). Family size and advertisements also play prominent role at the time of purchasing branded products (Ali et al, 2010).

The literature review showed that a number of factors drag the customers to purchase their clothes. These factors vary on the basis of area, income, gender, age etc. The previous studies were mostly done in other countries like India, Pakistan, USA and Europe. Moreover, these studies basically focused on the youth segment. Very few studies were found on this field in Bangladesh. So, this study focused on the factors that influence Bangladeshi people to purchase from local clothing brands.

\section{ObJectives of the Study}

The main objective of the study is to analyse the factors that influence the customers to purchase local clothing brands. Under this objective, there are some specific objectives which are: 
- To identify the factors those have great influence on purchase intention of clothing among different age groups.

- To investigate the factors those have significant impact on purchase intention of clothing among male and female customers.

- To examine the factors highly contributing to the purchase intention of clothing among various income groups.

\section{Methodology}

The study was descriptive in nature where a survey was done to prepare the paper. A closed-ended questionnaire was developed and used for the purpose of collecting data. Five factors were selected and mentioned in the questionnaires which are quality, variation, reasonable price, scope for change and promotional activities (HKTDC Research). Sample size (n) $=350$, where 200 were male and 150 were female respondents. Respondents are living in Dhaka, Chittagong and Sylhet; aged from 15 to 65 years old. They include students, doctors, teachers, executives, housewives and so on. A purposive sampling technique was chosen in order to make an unbiased survey. Cross tabulation analysis of SPSS 16 was used to analyse the data.

\section{ANALYSIS AND FINDINGS OF DATA \\ Explanation of Table 1}

Table-1 has given a picture of the reasons for which people at different ages are interested to use local clothing brands. From the table, it can be observed that $27.1 \%$ respondents purchase local brands for their superior quality. At least $20 \%$ respondents in every age group have agreed with this factor. In fact, the percentage is more than $30 \%$ for the age groups $45-55$ and 55-65. After that, variation and reasonable price are playing significant role in buying local clothes. Both these factors are chosen by $21.7 \%$ and $20 \%$ respondents respectively. Respondents aged between 15 and 35 years have shown more importance on variation. They prefer our local clothing brands because of their variation in shape, colour and cutting. On the other hand, the situation is a bit different for reasonable price. Only 1.6\% from age group 15-25 has accepted that they wear local brands because of their affordable price. Nevertheless, $17.1 \%$ and $14 \%$ respondents prefer our clothing brands for promotional activities and scope for change respectively. Promotional activities include advertisement, discount, and sale and so on. This factor has a great influence on the age group between 35 and 45 years.

\section{Explanation of Table 2}

Table-2 has depicted the difference between male and female customers regarding their choice of local clothing brands. Male customers more prefer local brands for their better quality. The table showed $29.5 \%$ male customers purchase from local brands because of quality, while the percentage of female customers is only $24 \%$. The table also gives an idea that female customers prefer local brands more than male customers for variation and reasonable price. For these factors, the rates of female consumers who prefer buying local clothes are $28 \%$ and $26.7 \%$ respectively. These percentages are a bit higher than that of male consumers. Moreover, scope for change has similar influence on both male and female users of local clothing brands. In contrast, promotional activities have a significant influence on the male customers instead of female customers. Table showed $26 \%$ male customers get attracted to local brands because of discount, sale, tvc and so on. It is only $5.3 \%$ for the female customers.

\section{Explanation of table 3}

Table-3 has depicted the factors that influence customers of different income group to purchase local clothing brands. Quality is an important factor for those who earn upto taka 40000 monthly. Other factors play minor role among the mentioned income group. This situation is similar to the customers whose per month earnings are among taka 80000 to taka 100000 . The percentages of customers who prefer local brands for quality are $44 \%$ and $31.6 \%$ for the income group 20000-40000 and 80000-100000 respectively. However, variation and reasonable price have significant influences for the customers having monthly income from taka 40,000 to taka 80000 . Nevertheless, customers who earn above taka 100000 like to have local clothing brands for quality, variation and promotional activities.

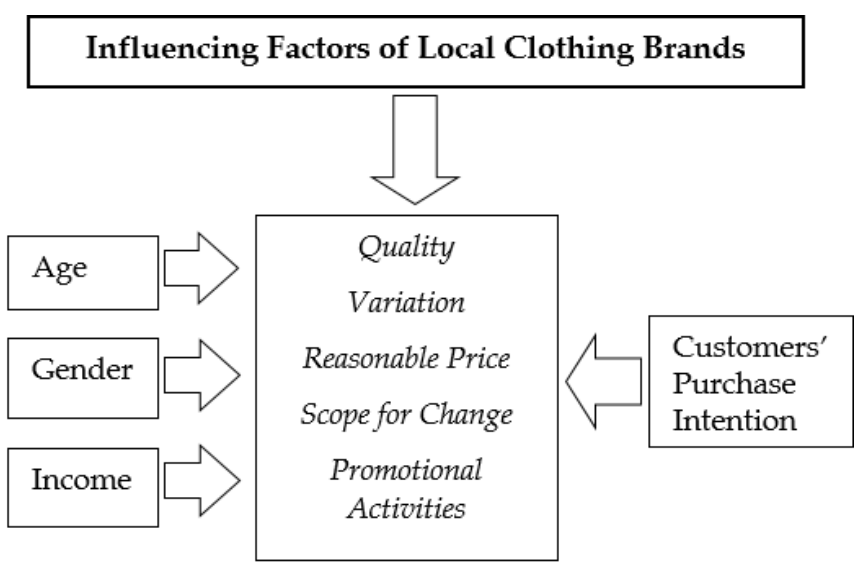

\section{LIMITATIONS OF THE STUDY}

The study is based on three cities of Bangladesh; Dhaka, Chittagong and Sylhet. Thus, the sample size compare to population is not very large. If the sample size could have been increased, the results might take different shape. Besides, people are sensitive to the preference of clothing brands in respect to their ages and incomes which might change the outputs of the study. Moreover, there were time and budget constrains for conducting this study. Nevertheless, only five factors are applied to get the idea about customers' purchase intention. Using more parameters could provide accurate reasons for buying local clothing brands. 


\section{CONCLUSION}

Styles and fashion in clothing industry changes rapidly around the world. Thus, popular and well-known brands are not always risk-free about the appreciation of their latest trends. Bangladesh is no exception to this. This paper reflects an understanding of customers' purchase intension towards local clothing brands. This study is useful for fashion houses and brands to promote and sell their products in our country.

\section{REFERENCES}

Ali et al. (2010). "Impact of Brand Image and Advertisement on Consumer Buying Behavior," World Applied Science Journal, Vol 23 (1), pp. 117-122.

Bentlar, P. M. and Speckart, G. (1979). "Models of Attitude Behavior Relations," Psychological Review, Vol 86, pp. 452-464.

Biplab S. B. (1998). Hand book of Marketing Management, Himalaya Publishing House.

Business Dictionary (2010), http://www.businessdictionary.com/ definition/purchase-intention.html

Cleveland, L., and Laroche, M. (2007). "Acculturaton to the global consumer culture: Scale development and research paradigm," Journal of Business Research, Vol 60 (3), pp. 249-259.

Delgado, E. and Ballester (2005). "Does Brand Trust Matter to Brand Equity?" Journal of Product and Brand Management, Vol 14 (3), pp. 187-196.

Dodds, B. K., Monroe, K. B. and Grewal, D. (1991). "Effect of price, brands and store information on buyers' product evaluation," Journal of Marketing Research, Vol 28, pp. 307-319.

Dodge, H. R., Edwards, E. A. and Fullerton, S. (1996). "Consumer transgressions in the marketplace: consumers' perspectives," Journal of Psychology and Marketing, Vol 13 (8), pp. 821-835.

Esch, F. R., Langner, T., Schmitt, B. H. and Geus, P. (2006). "Are brands forever? How brand knowledge and relationships affect current and future purchases," Journal of Product and Brand Management, Vol 15 (2), pp. 98-105.

Fitzsimons, Gavan J., and Morwitz V. G. (1996). "The Effect of Measuring Intent on Brand Level Purchase Behavior," Journal of Consumer Research, Vol 10, pp. 1-11.

Gino (2010). "The Impact on Branded Consumer Purchase Intention," Journal of Public Administration and Governance, Vol 4 (3), pp. 57-74.

Haque, A., Khatibi, A., and Rahman, S. (2009). "Factors influencing buying behavior of piracy and products and its impact to Malaysian Market," International Journal of Business Research, Vol (5), pp. 383-401.

Harvey, P. J., and Walls, W. D. (2003). "Laboratory Markets in Countrrfeit Goods: Ong Kong versus Las Vegas," Journal of Applied Economics, Vol (10), pp. 883-887.

Hsieh, M. H., Pan, S. L., Setiono R. (2004). "Product, corporate and country image," Journal of the Academy, pp. 251-270.

Jin, B., Kang, J. H., (2011). "Purchase Intention of Chinese Consumer perception toward a US Apparel Brand: A Test of a Composite Behavior Intention Model," Journal of Consumer Marketing, Vol 28 (3), pp. 14-19.

Kanthi, K. P. and Kumar, M. A. (2013). "A Study on Consumer Behavior towards Branded Garments among Male
Shoppers," Journal of Business and Management Invention, Vol 5 (5), pp. 45-49.

Kempf, D. S. and Smith, R. E. (1998). "Consumer Processing of Product of Trial and The Influence of Prior Advertising: A Structural Modeling Approach," Journal of Marketing Research, Vol , pp. 325-338.

Kinra, N. (2006). "The effect of country-of-origin on foreign brands names in the indian market." Journal of Marketing Intelligence and Planning, pp.15-30.

Kiron MI (2015), Readymade Garments Industry of Bangladesh, Available at: http://www.garmentsmerchandising.com/ readymade-garments-industry-of-bangladesh/

Lalitha. A., RaviKumar, J. and Pamavali, K. (2008). "Brand Preference of Men Wear." Indian Journal of Marketing, Vol 38 (10), pp. 33-36.

Laroche, M., Kim, C., and Zhou L. (1996). "Brand familiarity and confidence as determinants of purchase intention: an empirical test in a multiple brand context," Journal of Business Research, Vol 37 (2), pp. 115-120.

Miller, A. (1999). "Consumer Misbehavior: Why People Buy Illicit Goods?" Journal of Consumer Marketing, Vol 16 (3), pp. 273-287.

Mittal, S. and Aggarwal, A. (2012). "Consumer Behavior towards Branded Garments," IJRFM, Vol 2 (2), pp. 566-583.

Narang, R. (2006). "A Study on Branded Men's Wear," Indian Journal of Marketing, Vol 36 (11), pp. 3-9.

Narang, R. (2006). "A Study on Branded Men's Wear," Indian Journal of Marketing, Vol 36 (11), pp. 3-9.

Pandian et al. (2012). "Consumer Attitude towards Online Purchase- A Study with Reference to Branded Readymade Garments," Global Journal of Marketing Management and Research, Vol 6 (1), pp. 1-10.

Pathak, S. V. and Aditya, P. T. (2009). "Consumer shopping behaviour among Modern Retail Formats: A Study of Delhi and NCR," Indian Journal of Marketing, Vol 39 (2), pp. 3-12.

Pathak, S. V. and Aditya, P. T. (2009). "Consumer shopping behaviour among Modern Retail Formats: A Study of Delhi and NCR," Indian Journal of Marketing, Vol 39 (2), pp. 3-12.

Prendergast, G., Chuen, L. H. and Phau, I. (2002). "Understandng Consumer Demand for Non-deceptive pirated Brands," Journal of Marketing Intelligence and Planning, Vol 20 (7), pp. 405-416.

Rajput, N. (2012). "Consumer's Attitude towards Branded Apparels: Canadian Centre of Science and Education, Vol 4 (2), pp. 111-120.

Rizwan, M., Imran, M., Qayyum, A., Yousaf, M., Qaiser, S., Afzal, S. And Fatima, N. (2013). "Consumer's purchase intention towards Counterfeit Mobile Phones," IOSR Journal of Business and Management, Vol 1 (special issue), pp. 36-43.

Sawant, P. R. (2012). "Impact of Advertising on Brand Awareness and Consumer Preference," Indian Journal of Business and Management, Vol 5 (1), pp. 54-61.

Vikkraman, P. and Sumathi, N. (2012). "Purchase Behavior in Indian Apparel Market," Indian Journal of Multidisciplinary Research, Vol 12 (2), pp. 1-12.

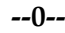




\section{Appendices}

\section{Case Processing Summary}

\begin{tabular}{|c|c|c|c|c|c|}
\hline \multicolumn{5}{|c|}{ Cases } \\
\hline \multicolumn{2}{|c|}{ Valid } & \multicolumn{2}{|c|}{ Missing } & \multicolumn{2}{|c|}{ Total } \\
\hline $\mathrm{N}$ & Percent & $\mathrm{N}$ & Percent & $\mathrm{N}$ & Percent \\
\hline 350 & $100.0 \%$ & 0 & $.0 \%$ & 350 & $100.0 \%$ \\
\hline
\end{tabular}

Table 1

\begin{tabular}{|c|c|c|c|c|c|c|c|c|}
\hline \multicolumn{9}{|c|}{ Age ${ }^{*}$ Factors Cross Tabulation } \\
\hline & & & \multicolumn{5}{|c|}{ Factors } & \multirow[b]{2}{*}{ Total } \\
\hline & & & Quality & Variation & $\begin{array}{c}\text { Reasonable } \\
\text { Price }\end{array}$ & $\begin{array}{l}\text { Return } \\
\text { ability }\end{array}$ & $\begin{array}{c}\text { Promotional } \\
\text { Activities }\end{array}$ & \\
\hline \multirow[t]{20}{*}{ Age } & \multirow[t]{4}{*}{$15-25$} & Count & 20 & 22 & 1 & 12 & 8 & 63 \\
\hline & & $\%$ within Age & $31.7 \%$ & $34.9 \%$ & $1.6 \%$ & $19.0 \%$ & $12.7 \%$ & $100.0 \%$ \\
\hline & & $\%$ within Factors & $21.1 \%$ & $28.9 \%$ & $1.4 \%$ & $24.5 \%$ & $13.3 \%$ & $18.0 \%$ \\
\hline & & $\%$ of Total & $5.7 \%$ & $6.3 \%$ & $.3 \%$ & $3.4 \%$ & $2.3 \%$ & $18.0 \%$ \\
\hline & \multirow[t]{4}{*}{$25-35$} & Count & 19 & 24 & 24 & 9 & 10 & 86 \\
\hline & & $\%$ within Age & $22.1 \%$ & $27.9 \%$ & $27.9 \%$ & $10.5 \%$ & $11.6 \%$ & $100.0 \%$ \\
\hline & & $\%$ within Factors & $20.0 \%$ & $31.6 \%$ & $34.3 \%$ & $18.4 \%$ & $16.7 \%$ & $24.6 \%$ \\
\hline & & $\%$ of Total & $5.4 \%$ & $6.9 \%$ & $6.9 \%$ & $2.6 \%$ & $2.9 \%$ & $24.6 \%$ \\
\hline & \multirow[t]{4}{*}{$35-45$} & Count & 21 & 13 & 22 & 18 & 22 & 96 \\
\hline & & $\%$ within Age & $21.9 \%$ & $13.5 \%$ & $22.9 \%$ & $18.8 \%$ & $22.9 \%$ & $100.0 \%$ \\
\hline & & $\%$ within Factors & $22.1 \%$ & $17.1 \%$ & $31.4 \%$ & $36.7 \%$ & $36.7 \%$ & $27.4 \%$ \\
\hline & & $\%$ of Total & $6.0 \%$ & $3.7 \%$ & $6.3 \%$ & $5.1 \%$ & $6.3 \%$ & $27.4 \%$ \\
\hline & \multirow[t]{4}{*}{$45-55$} & Count & 15 & 7 & 14 & 7 & 2 & 45 \\
\hline & & $\%$ within Age & $33.3 \%$ & $15.6 \%$ & $31.1 \%$ & $15.6 \%$ & $4.4 \%$ & $100.0 \%$ \\
\hline & & $\%$ within Factors & $15.8 \%$ & $9.2 \%$ & $20.0 \%$ & $14.3 \%$ & $3.3 \%$ & $12.9 \%$ \\
\hline & & $\%$ of Total & $4.3 \%$ & $2.0 \%$ & $4.0 \%$ & $2.0 \%$ & $.6 \%$ & $12.9 \%$ \\
\hline & \multirow[t]{4}{*}{$55-65$} & Count & 20 & 10 & 9 & 3 & 18 & 60 \\
\hline & & $\%$ within Age & $33.3 \%$ & $16.7 \%$ & $15.0 \%$ & $5.0 \%$ & $30.0 \%$ & $100.0 \%$ \\
\hline & & $\%$ within Factors & $21.1 \%$ & $13.2 \%$ & $12.9 \%$ & $6.1 \%$ & $30.0 \%$ & $17.1 \%$ \\
\hline & & $\%$ of Total & $5.7 \%$ & $2.9 \%$ & $2.6 \%$ & $.9 \%$ & $5.1 \%$ & $17.1 \%$ \\
\hline \multirow{4}{*}{\multicolumn{2}{|c|}{ Total }} & Count & 95 & 76 & 70 & 49 & 60 & 350 \\
\hline & & $\%$ within Age & $27.1 \%$ & $21.7 \%$ & $20.0 \%$ & $14.0 \%$ & $17.1 \%$ & $100.0 \%$ \\
\hline & & $\%$ within Factors & $100.0 \%$ & $100.0 \%$ & $100.0 \%$ & $100.0 \%$ & $100.0 \%$ & $100.0 \%$ \\
\hline & & $\%$ of Total & $27.1 \%$ & $21.7 \%$ & $20.0 \%$ & $14.0 \%$ & $17.1 \%$ & $100.0 \%$ \\
\hline
\end{tabular}




\section{Case Processing Summary}

\begin{tabular}{|l|c|c|c|c|c|c|}
\hline \multirow{2}{*}{} & \multicolumn{6}{|c|}{ Cases } \\
\cline { 2 - 7 } & \multicolumn{2}{|c|}{ Valid } & \multicolumn{2}{c|}{ Missing } & \multicolumn{2}{c|}{ Total } \\
\cline { 2 - 7 } & $\mathrm{N}$ & Percent & $\mathrm{N}$ & Percent & $\mathrm{N}$ & Percent \\
\hline Gender * Factors & 350 & $100.0 \%$ & 0 & $.0 \%$ & 350 & $100.0 \%$ \\
\hline
\end{tabular}

Table 2

\begin{tabular}{|c|c|c|c|c|c|c|c|c|}
\hline \multicolumn{9}{|c|}{ Gender ${ }^{*}$ Factors Cross Tabulation } \\
\hline & & & \multicolumn{5}{|c|}{ Factors } & \multirow[b]{2}{*}{ Total } \\
\hline & & & Quality & Variation & $\begin{array}{c}\text { Reasonable } \\
\text { Price }\end{array}$ & $\begin{array}{l}\text { Return } \\
\text { ability }\end{array}$ & $\begin{array}{l}\text { Promotional } \\
\text { Activities }\end{array}$ & \\
\hline \multirow[t]{8}{*}{ Gender } & \multirow[t]{4}{*}{ Male } & Count & 59 & 34 & 30 & 25 & 52 & 200 \\
\hline & & $\%$ within Gender & $29.5 \%$ & $17.0 \%$ & $15.0 \%$ & $12.5 \%$ & $26.0 \%$ & $100.0 \%$ \\
\hline & & $\%$ within Factors & $62.1 \%$ & $44.7 \%$ & $42.9 \%$ & $51.0 \%$ & $86.7 \%$ & $57.1 \%$ \\
\hline & & $\%$ of Total & $16.9 \%$ & $9.7 \%$ & $8.6 \%$ & $7.1 \%$ & $14.9 \%$ & $57.1 \%$ \\
\hline & \multirow[t]{4}{*}{ Female } & Count & 36 & 42 & 40 & 24 & 8 & 150 \\
\hline & & $\%$ within Gender & $24.0 \%$ & $28.0 \%$ & $26.7 \%$ & $16.0 \%$ & $5.3 \%$ & $100.0 \%$ \\
\hline & & $\%$ within Factors & $37.9 \%$ & $55.3 \%$ & $57.1 \%$ & $49.0 \%$ & $13.3 \%$ & $42.9 \%$ \\
\hline & & $\%$ of Total & $10.3 \%$ & $12.0 \%$ & $11.4 \%$ & $6.9 \%$ & $2.3 \%$ & $42.9 \%$ \\
\hline \multirow{4}{*}{\multicolumn{2}{|c|}{ Total }} & Count & 95 & 76 & 70 & 49 & 60 & 350 \\
\hline & & $\%$ within Gender & $27.1 \%$ & $21.7 \%$ & $20.0 \%$ & $14.0 \%$ & $17.1 \%$ & $100.0 \%$ \\
\hline & & $\%$ within Factors & $100.0 \%$ & $100.0 \%$ & $100.0 \%$ & $100.0 \%$ & $100.0 \%$ & $100.0 \%$ \\
\hline & & $\%$ of Total & $27.1 \%$ & $21.7 \%$ & $20.0 \%$ & $14.0 \%$ & $17.1 \%$ & $100.0 \%$ \\
\hline
\end{tabular}


Case Processing Summary

\begin{tabular}{|c|c|c|c|c|c|c|}
\hline \multirow{2}{*}{} & \multicolumn{9}{|c|}{ Cases } \\
\cline { 2 - 7 } & \multicolumn{2}{|c|}{ Valid } & \multicolumn{2}{c|}{ Missing } & \multicolumn{2}{c|}{ Total } \\
\cline { 2 - 7 } & $\mathrm{N}$ & Percent & $\mathrm{N}$ & Percent & $\mathrm{N}$ & Percent \\
\hline Income * Factors & 350 & $100.0 \%$ & 0 & $.0 \%$ & 350 & $100.0 \%$ \\
\hline
\end{tabular}

Table 3

\begin{tabular}{|c|c|c|c|c|c|c|c|c|}
\hline \multicolumn{9}{|c|}{ Income ${ }^{*}$ Factors Cross Tabulation } \\
\hline & & & \multicolumn{5}{|c|}{ Factors } & \multirow[b]{2}{*}{ Total } \\
\hline & & & Quality & Variation & $\begin{array}{c}\text { Reasonable } \\
\text { Price }\end{array}$ & $\begin{array}{l}\text { Return } \\
\text { Ability }\end{array}$ & $\begin{array}{c}\text { Promotional } \\
\text { Activities }\end{array}$ & \\
\hline \multirow[t]{20}{*}{ Income } & \multirow[t]{4}{*}{$20000-40000$} & Count & 22 & 3 & 14 & 6 & 5 & 50 \\
\hline & & $\%$ within Income & $44.0 \%$ & $6.0 \%$ & $28.0 \%$ & $12.0 \%$ & $10.0 \%$ & $100.0 \%$ \\
\hline & & \% within Factors & $23.2 \%$ & $3.9 \%$ & $20.0 \%$ & $12.2 \%$ & $8.3 \%$ & $14.3 \%$ \\
\hline & & $\%$ of Total & $6.3 \%$ & $.9 \%$ & $4.0 \%$ & $1.7 \%$ & $1.4 \%$ & $14.3 \%$ \\
\hline & \multirow[t]{4}{*}{$40000-60000$} & Count & 17 & 37 & 13 & 15 & 6 & 88 \\
\hline & & $\%$ within Income & $19.3 \%$ & $42.0 \%$ & $14.8 \%$ & $17.0 \%$ & $6.8 \%$ & $100.0 \%$ \\
\hline & & $\%$ within Factors & $17.9 \%$ & $48.7 \%$ & $18.6 \%$ & $30.6 \%$ & $10.0 \%$ & $25.1 \%$ \\
\hline & & $\%$ of Total & $4.9 \%$ & $10.6 \%$ & $3.7 \%$ & $4.3 \%$ & $1.7 \%$ & $25.1 \%$ \\
\hline & \multirow[t]{4}{*}{$60000-80000$} & Count & 20 & 15 & 28 & 11 & 14 & 88 \\
\hline & & $\%$ within Income & $22.7 \%$ & $17.0 \%$ & $31.8 \%$ & $12.5 \%$ & $15.9 \%$ & $100.0 \%$ \\
\hline & & $\%$ within Factors & $21.1 \%$ & $19.7 \%$ & $40.0 \%$ & $22.4 \%$ & $23.3 \%$ & $25.1 \%$ \\
\hline & & $\%$ of Total & $5.7 \%$ & $4.3 \%$ & $8.0 \%$ & $3.1 \%$ & $4.0 \%$ & $25.1 \%$ \\
\hline & \multirow[t]{4}{*}{$80000-100000$} & Count & 25 & 12 & 9 & 15 & 18 & 79 \\
\hline & & $\%$ within Income & $31.6 \%$ & $15.2 \%$ & $11.4 \%$ & $19.0 \%$ & $22.8 \%$ & $100.0 \%$ \\
\hline & & $\%$ within Factors & $26.3 \%$ & $15.8 \%$ & $12.9 \%$ & $30.6 \%$ & $30.0 \%$ & $22.6 \%$ \\
\hline & & $\%$ of Total & $7.1 \%$ & $3.4 \%$ & $2.6 \%$ & $4.3 \%$ & $5.1 \%$ & $22.6 \%$ \\
\hline & \multirow[t]{4}{*}{ 100000-More } & Count & 11 & 9 & 6 & 2 & 17 & 45 \\
\hline & & $\%$ within Income & $24.4 \%$ & $20.0 \%$ & $13.3 \%$ & $4.4 \%$ & $37.8 \%$ & $100.0 \%$ \\
\hline & & $\%$ within Factors & $11.6 \%$ & $11.8 \%$ & $8.6 \%$ & $4.1 \%$ & $28.3 \%$ & $12.9 \%$ \\
\hline & & $\%$ of Total & $3.1 \%$ & $2.6 \%$ & $1.7 \%$ & $.6 \%$ & $4.9 \%$ & $12.9 \%$ \\
\hline \multirow{4}{*}{\multicolumn{2}{|c|}{ Total }} & Count & 95 & 76 & 70 & 49 & 60 & 350 \\
\hline & & $\%$ within Income & $27.1 \%$ & $21.7 \%$ & $20.0 \%$ & $14.0 \%$ & $17.1 \%$ & $100.0 \%$ \\
\hline & & $\%$ within Factors & $100.0 \%$ & $100.0 \%$ & $100.0 \%$ & $100.0 \%$ & $100.0 \%$ & $100.0 \%$ \\
\hline & & $\%$ of Total & $27.1 \%$ & $21.7 \%$ & $20.0 \%$ & $14.0 \%$ & $17.1 \%$ & $100.0 \%$ \\
\hline
\end{tabular}




\section{SOCIAL SCIENCE RESEARCH NETWORK}

2171 Monroe Avenue, Suite 203, Rochester, NY 14618, USA http://www.ssrn.com/en/

AJTP Link: http://www.ssrn.com/link/American-Journal-Trade-Policy.html 